\title{
"Sermão de Santo Antônio aos peixes" ou a metáfora do imaginário colonial português
}

\author{
"Sermão de Santo Antônio aos peixes" or the metaphor \\ of colonial Portuguese imaginary
}

\author{
ERNANI MÜGGE \\ Universidade Feevale \\ DANIEL CONTE \\ Universidade Feevale-CNPq
}

\begin{abstract}
Resumo: O presente artigo analisa as críticas dirigidas aos colonos portugueses, presentes no "Sermão de Santo Antônio aos Peixes", à luz do contexto no qual foi produzido, com o intuito de identificar particularidades do momento histórico e social do Maranhão e do Grão-Pará, região circunscrita à atuação do Padre Antônio Vieira. O sermão é enunciado em 1654, depois do retorno de Pe. Vieira ao Brasil e antes de dirigir-se novamente a Portugal, para denunciar o descumprimento, pelos colonos, das leis de proteção aos indígenas. Tendo o sermão por base, o artigo evidencia que a literatura se vale de aspectos e episódios do mundo em que é produzida, para transfigurá-los e devolvê-los ao leitor, em forma de ficção, conscientizando-o das denúncias de que é porta-voz.
\end{abstract}

Palavras-chave: Sermão; Padre Vieira; Imaginário Colonial; Portugal

\begin{abstract}
The present article analyzes the criticism directed at the Portuguese colonists, which appears in the "Sermon of Saint Anthony to the Fish", considering the context in which it was produced, aiming to identify the specificities of the historical and social moment in Maranhão and Grão Pará, which region was circumscribed to the activities of Father Antonio Vieira. The sermon was made in 1654, after Padre Vieira returned to Brazil and before he went back to Portugal again to denounce the fact that the colonists were not obeying the laws of protection to the indigenous people. Based on the sermon, the article takes the position that literature uses aspects and episodes of the world in which it is produced to transfigure them and return them to the reader in the form of fiction, making them aware of the denunciations they carry.
\end{abstract}

Keywords: Sermão; Padre Vieira; Colonial Imaginary; Portugal

Ancorada na rede de significações do imaginário, que lhe serve de matéria-prima, a literatura expressa aspectos políticos, econômicos, sociais e culturais de um povo. Nessa ordem, é possível identificar na literatura brasileira momentos da história do país em seus processos formativos e, por conseguinte, atores que materializam literariamente traços de sua sociedade, o que evidencia as nuances performativas da identidade nacional.

Dentre os grandes nomes da literatura brasileira, Padre Vieira ocupa um lugar significativo por seu trabalho e por sua vasta produção, que totaliza 207 sermões, textos exegéticos, profecias, cartas e relatórios políticos. Alfredo Bosi define a pluridentidade de Vieira, ao observar que no papel de "Jesuíta, conselheiro de reis, confessor de rainhas, preceptor de príncipes, diplomata em cortes europeias, defensor de cristãos novos e com igual zelo missionário no Maranhão e no Pará, Vieira traz em si uma estatura e um horizonte internacional” (1989, p. 28). Dos inúmeros trabalhos do autor, o "Sermão de Santo Antônio aos Peixes" insere-se em uma perspectiva de denúncia do imaginário colonial português, de sua crueldade e da efetivação da violência cultural congênita. Pregado em São Luís do Maranhão, em 13 de junho de 1654, constituise em importante documento acusatório das injustiças e contradições da sociedade do período, especificamente a da região do Maranhão e Grão-Pará, marcada pelo domínio dos colonos, ávidos pelo poder, que sustentam sua produção agrícola na escravidão indígena e negra. 
O sermão expressa a indignação do missionário diante do contexto em que os preceitos cristãos são abafados pelos interesses pessoais e corporativistas, os quais mantêm, por exemplo, a escravidão indígena, o que se ergue como ponto central dos conflitos entre colonos e jesuítas. Ao passo que os primeiros lutam pela continuidade da exploração de mão de obra indígena, ignorando as leis ${ }^{1}$; os missionários defendem a libertação destes povos.

Nesse clima de disputa e indignação, que grassa em ambos os lados, irrompe o "Sermão de Santo Antônio aos Peixes", que é proferido dias antes de o padre jesuíta embarcar novamente para Portugal, a fim de denunciar, junto à corte, as arbitrariedades contra os indígenas, que constatara em seu retorno ao Brasil. O sermão presentifica a figura do proeminente santo católico - Santo Antônio de Lisboa, ou de Pádua (1191 ou 1195-1231) - cuja iniciativa de pregar aos peixes, ainda como Frei Antônio, é imitada por Vieira. Tal qual o predecessor, que, em 1223, na cidade de Rimini, dirige seu sermão aos peixes na costa do mar Adriático, em protesto contra os hereges da região os quais impediam o povo de assistir a suas pregações; Vieira também invoca os peixes, devido à indiferença dos fiéis, para estabelecer considerações sobre virtudes e vícios humanos. Ao fazê-lo, refere-se a alguns peixes conhecidos na região do Maranhão, como o roncador, o pegador, o voador e o polvo, instalando uma relação metafórica com os colonizadores, a fim de provocar um efeito de sentido mais contundente entre os ouvintes.

$\mathrm{O}$ interesse pela obra do Pe. Vieira "só tem a ganhar se for norteado por um empenho interpretativo que consiga extrair dela a riqueza das suas contradições, que são as do sistema colonial como um todo, e que só a experiência brasileira, de per si, não explica" (BOSI, 1992, p. 119). Nesse sentido, justifica-se a análise que segue, à medida em que busca compreender e evidenciar aspectos da realidade brasileira do século XVII, inscritas no texto e o tratamento estético que lhe é dispensado.

\section{Vieira e o contexto da primeira metade do século XVII}

O século XVII caracteriza-se por importantes eventos históricos que influenciam o posicionamento de Antônio Vieira e, em consequência, sua materialidade literária que emerge de sua visão de mundo. Dentre os eventos, os mais

\footnotetext{
1 Importante registrar que em 1570, a Coroa publicou a primeira lei que proibia a escravização de indígenas; seguiram-se a de 1609, que reafirmou a liberdade dos povos originários do Brasil; a de 1686, que decretou o "Regimento das Missões", regulamentando o trabalho missionário e o fornecimento de mão de obra indígena no Maranhão e Grão-Pará; a de 1755 , que, por meio de medidas específicas, visou à integração do nativo à colônia e proibia a escravidão indígena; a de 1758, que, finalmente, pôs fim à escravidão indígena. (Fonte: IBGE)
}

significativos são a Contrarreforma, a Guerra Holandesa (1624-1654) e a restauração do reino de Portugal após sessenta anos sob domínio espanhol (1580-1640). No Brasil, à época, a monocultura se consolidava pelas mãos dos colonos, que buscavam ampliar sua produção às custas da mão de obra escrava (cf. BAER, 2011, p. 29).

Padre Vieira é fruto do movimento da Contrarreforma, constituído pela Igreja Católica em função do surgimento e do avanço das religiões protestantes, que deu origem à Companhia de Jesus. Aos jesuítas, coube a tarefa de expandir o catolicismo pelo mundo, por meio da evangelização, e chegaram ao Brasil em março de 1549, junto com o primeiro governador-geral, Tomé de Souza, com o objetivo de catequizar os indígenas. Em solo brasileiro, além de se dedicar à sua missão precípua, fundaram inúmeras escolas, entre as quais, o Colégio dos Jesuítas de Salvador, que recebeu Antônio Vieira, como aluno, em 1614. Ingressou na Companhia de Jesus em 1623, e um ano depois, em função da invasão dos holandeses ${ }^{2}$, refugiou-se no interior da capitania, onde deu início à vocação missionária. Dois anos depois, fez os votos do noviciado e, em 1626, foi encarregado de redigir a Carta Ânua, assumindo a cadeira de Retórica no Colégio Jesuíta de Olinda.

Corria o ano de 1641 quando partiu para Portugal, retornando ao Brasil somente em 1653 e radicando-se no Maranhão ${ }^{3}$. No período em que esteve além-mar, desenvolveu diversas atividades: ocupou a função de pregador régio, conselheiro e embaixador de D. João IV, entretanto, suas atividades em Portugal lhe causaram dissabores ${ }^{4}$. Saraiva \& Lopes observam que

António Vieira recomendou uma política fundada no poder económico da burguesia mercantil, constituída pelos cristãos-novos [...] intentou Vieira financiar a guerra da independência, mas para isso era necessário moderar a política inquisitorial de repressão e discriminação. E, evidentemente, esta política tinha contra si, o Santo Ofício, que não representava a penas

\footnotetext{
2 Antônio Vieira relata a invasão holandesa, a fuga e o estabelecimento dos desterrados no interior na Carta Ânua 1, p. 13-19, disponível em: <http:/ www.brasiliana.usp.br/bbd/handle/1918/01951310\#page/38/mode/1up> Acesso em: 16 fev. 2015.

3 Em 1649, Pe. Vieira sofre pressão de seus confrades por seu envolvimento político e, por consequência, afastamento dos púlpitos, especialmente nos dois anos anteriores. O Geral chega a ordenar que Vieira seja intimado a transferir-se para outra ordem religiosa. Conforme Besselar (1981, p. 17), "não é de estranhar que o novo professo, ocupando uma posição excepcional entre os seus confrades, lhes causasse escândalo e até inveja, sobretudo depois das suas viagens ao estrangeiro, onde trocava a roupeta de jesuíta pela grã de fidalgo."

4 Vieira não obteve sucesso nas empreitadas diplomáticas na França e na Holanda, com quem Portugal intentava estreitar relações a fim de solidificar sua restauração. Além disso, a fundação, em 1649, da Companhia Geral de Comércio do Brasil, ideia defendida por Vieira, financiada com capitais de mercadores judeus e cristãos-novos, isentos de impostos, contrariava os interesses do Santo Ofício e afetou diretamente a relação do jesuíta com sua ordem.
} 
uma tradição já secular de intolerância religiosa, mas também uma rede extensa de gente a viver de confiscos e sinecuras [...] (SARAIVA e LOPES, 2010, p. 518).

Seu retorno ao Brasil deu-se, portanto, a partir de uma desilusão íntima, o que certamente contribuiu para fortalecer a acidez do "Sermão de Santo Antônio aos Peixes", mesmo que o alvo das críticas não fossem os detentores do poder político e religioso da corte portuguesa, mas os colonos portugueses, que sintetizavam a perversidade do mecanismo colonial de Portugal.

Antônio Vieira chegou ao Maranhão a 16 de janeiro de 1653, na véspera do dia de Santo Antão. Sua primeira impressão sobre o lugar encontra-se em uma carta enviada ao Príncipe Dom Teodósio, em 25 de janeiro:

O desamparo e necessidade espiritual que aqui se padece é verdadeiramente extremo; porque os gentios e os cristãos todos vivem quase em igual cegueira, por falta de cultura e doutrina, não havendo quem catequize nem administre sacramentos: havendo, porém, quem cative e quem tiranize, e, o que é pior, quem o aprove; com que portugueses e índios todos se vão ao Inferno (AZEVEDO, 2008, p. 233).

A realidade que indignava o missionário, e que virá a ser o mote da pregação do "Sermão de Santo Antônio aos Peixes", se refere à captura dos indígenas da região circunscrita à sua atividade. Quatro meses mais tarde, em carta a D. João IV, Vieira descreve a situação dos indígenas:

Os moradores deste novo mundo (que assim se pode chamar) ou são portugueses, ou índios naturais da terra. Os índios uns são gentios que vivem nos sertões, infinitos no número, e diversidade de línguas: outros são pela maior parte cristãos que vivem entre os portugueses. Destes que vivem entre os portugueses, uns são livres, que estão em suas aldeias: outros são parte livres, parte cativos, que moram com os mesmos portugueses, e os servem em suas casas e lavouras, e sem os quais eles de nenhuma maneira se podem $\operatorname{sustentar}^{5}(1871$, p. 40).

Logo em seguida, assevera que os portugueses vivem "em necessidade espiritual pouco menos que extrema", apontando a falta de curas e párocos como uma das causas desse estado de penúria. Manifesta, ademais, sua preocupação em relação aos indígenas que vivem nas casas dos portugueses, igualmente desassistidos em termos espirituais. Nela, denuncia a perpetuação do padecimento, tal como muitas vezes já informara; os efeitos da cobiça, visto que os portugueses de maior posse ordenavam a

\footnotetext{
5 Foi feita uma adaptação da ortografia e da estrutura sintática, quando essa facilitou a compreensão, dos excertos das cartas de Antônio Vieira.
}

abertura de estradas pelos sertões, promoviam guerras e aprisionavam indígenas. As medidas outrora tomadas por D. João IV, e por vários de seus antecessores, para acabar com a tirania de "cerrar os sertões e proibir que houvessem resgates e declarar por livres todos os já resgatados" (VIEIRA, 1871, p.44), apesar de ser o mais eficiente, configurava-se "dificultosíssima", devido às condições geoculturais. Desse modo, propõe que se examinem os cativeiros, com a finalidade de libertar os homens livres e de manter cativos os escravos (p.45), estabelecendo-se o cumprimento da lei. Adverte, ainda, que este exame deve ser feito com "a inteireza e justiça que convém". Sugere, ainda, que as entradas ao sertão sejam feitas apenas para converter aos gentios e reduzilos à sujeição da igreja e da coroa, e que o capitão encarregado da empreitada não seja eleito somente pelo capitão-mor, pois este atenderá mais a seus próprios interesses que aos de Deus e do bem comum.

Sobre os indígenas que habitam nas aldeias, com o título de livres, Padre Vieira constata que são muito mais cativos que aqueles que moram nas casas dos portugueses, uma vez que estão em pior condição que os escravos, pois precisam trabalhar nas lavouras de tabaco, "que é o mais cruel trabalho que há no Brasil" (VIEIRA, 1871, p.47). Registra Vieira o modo com que os indígenas são tratados: "mandam-nos servir violentamente a pessoas, e em serviços a que não vão senão forçados, e morrem lá de puro sentimento: tiram as mulheres casadas das aldeias e põem-nas a servir em casas particulares [...], enfim, em tudo são tratados como escravos" (VIEIRA, 1871, p. 47). E segue seu desalento: "os tristes índios estão hoje quase acabados e consumidos, e para não acabarem de se consumir de todo, estiveram abaladas as aldeias este ano para se passarem a outras terras onde vivessem fora desta sujeição tão mal sofrida" (VIEIRA, 1871, p.47).

Como solução para o problema, o Padre elenca as seguintes medidas, evidenciando sua posição políticoideológica, que o havia maculado na corte portuguesa anos antes, entre as proposições, estavam a proibição do cultivo do tabaco e congêneres; recorrência ao trabalho dos nativos somente para erguer fortificações ou para outros serviços de Sua Majestade; coibição da instalação de capitães nas aldeias, as quais deveriam ser governadas pelos governadores; permissão para que os religiosos visitassem as aldeias ou nelas residissem, como era hábito. Somente dessa maneira, entende o Padre, as aldeias poderiam ser conservadas e redimensionadas, permitindo que seus habitantes vivessem como cristãos.

Vieira percebe as imagens da violência colonial e a violação do campo imaginário dos nativos brasileiros. É certo que associa isso ao binarismo sucesso/fracasso da evangelização, contudo, faz-se importante perceber a posição, o locus de enunciação do missionário, porque 
articula em sua súplica a relação ritualística das imagens, o que Durand sintetiza quando assevera que "é pela imagem que a alma humana representa com maior exatidão ainda as virtudes da santidade" (1994, p. 19).

Após a carta-resposta de D. João IV, Vieira retribuilhe a venia com outra, datada em 04 de abril de 1654, na qual novamente mostra sua desilusão com a organização sistêmica do colonialismo lusitano e suas estratégias espoliativas, declarando que os colonos "antes preferem cinquenta que os sirvam, ainda que morram quinhentos, que milhares vivos e conservados, dos quais eles não podem se valer" (1871, p.66). Manifesta sua revolta contra o capitão-mor N. do N., que ordenara trazer indígenas para aldeias próximas à sua plantação de tabaco, ignorando a autoridade que Vossa Majestade havia concedido a Vieira de instalá-los nas aldeias que considerasse mais apropriadas. Ainda na mesma carta, remonta aos desmandos do capitão-mor e de seu mandado, Gaspar Cardoso que, em uma expedição a Tocantins, teria usado de promessas, ameaças e mentiras para convencer os indígenas do lugar a acompanhá-lo. O padre relata desta maneira o episódio:

[...] mas Gaspar Cardoso e os seus, parte com promessas, parte com ameaças, parte com lhes darem demasiadamente de beber, e os tirarem de seu juízo, parte com lhes dizerem que os padres haviam de tirar aos principais as muitas mulheres que costumavam ter, para com isto os alienarem de nós: com estas e outras semelhantes violências e impiedades arrancaram de suas terras metade dos índios que ali estavam, (e seriam por todo mil almas) e os trouxeram pelo rio abaixo; e depois de Gaspar repartir alguns pelos soldados, e levar outros para sua casa, a maior parte de todos se puseram em uma aldeia chamada Morajuba, sem embargo de não haver nela mantimento algum para se sustentarem, mas é esta aldeia a que está mais perto dos tabacos de N. do N. (1871, p. 70, 71).

As imagens que emergem das cartas de Vieira mostram um embate entre os interesses dos capitães e dos missionários jesuítas, no qual estes estão em desvantagem, apesar de contarem com o apoio da Corte. Inconformado com os despropósitos da colonização, Vieira desabafa alcunhando de "bárbaros das brenhas", "inimigos ou estranhos" (1871, p. 72) os capitães a quem confiara seus estados e a quem encomendara a conversão das almas.

O "Sermão de Santo Antônio aos Peixes" é concebido e pregado nesse contexto. Construído sob a égide da retórica barroca, traduz o modus vivendi da região à época, constituindo-se, assim, em importante documento ${ }^{6}$

\footnotetext{
6 Apesar de ser orientado por finalidades práticas, como a propagação da fé e a aceitação dos preceitos cristãos, os sermões inserem-se, hoje, no cânone literário, por suas qualidades estéticas, o que justifica sua análise no âmbito dos estudos literários.
}

de análise, mormente quando seu teor é relacionado aos eventos históricos.

\section{O "sermão de Santo Antônio aos peixes": denúncia da sociedade brasileira do período colonial}

O "Sermão de Santo Antônio aos Peixes" é um dos textos mais pessimistas de Antônio Vieira. Pregado na cidade de São Luís do Maranhão, no ano de 1654, o sermão apresenta as virtudes e os vícios da sociedade brasileira recém-constituída, com o claro objetivo de comover e persuadir seu público, constituído de colonos, de fazêlos olhar para si mesmos e de convencê-los de que estão equivocados em relação às suas atitudes e comportamentos.

Vieira divide o sermão em seis partes e inicia-o referindo-se ao episódio em que Jesus, ao falar com seus apóstolos, os denomina de "sal da terra", esperando que eles alcancem, com sua prática missionária, o mesmo que o sal: preservar ${ }^{7}$. No entanto, diante da realidade maranhense colocada à contemplação, questiona: "O efeito do sal é impedir a corrupção, mas quando a terra se vê tão corrupta como está a nossa, havendo tantos nela que têm ofício de sal, qual será, ou qual pode ser a causa desta corrupção?" (p. 429) ${ }^{8}$. Como resposta, aponta duas possibilidades: "Ou é porque o sal não salga, ou porque a terra se não deixa salgar" (p. 429).

A explicação para a situação dos maranhenses estaria, portanto, na ineficiência dos pregadores e na insensibilidade das pessoas. Assim sendo, questiona-se sobre o que deve ser feito para dar novos rumos à sociedade. Para responder à questão que se refere aos pregadores, novamente recorre aos ensinamentos de Cristo: "se o sal vier a ser insípido, como lhe restaurar o sabor? Para nada mais presta senão para, lançado fora, ser pisado pelos homens" "(BÍBLIA, 1999, Mt. 5, 13). Quanto à insensibilidade das pessoas, afirma que nem mesmo Jesus foi capaz de eliminá-la. Nessa ordem, reproduz a atitude de Santo Antônio, que, ao invés de pregar aos homens, pregou aos peixes, bradando "Já que me não querem ouvir os homens, ouçam-me os peixes" (p. 431). Vieira anuncia: "quero hoje, à imitação de Santo Antônio, voltar-me da terra ao mar, e já que os homens se não aproveitam, pregar aos peixes. O mar está tão perto que bem me ouvirão. Os demais podem deixar o sermão, pois não é para eles".

\footnotetext{
Esse conceito é trabalhado por Vieira de forma mais detalhada no "Sermão de Santo Antônio", quando explicita que Jesus Cristo primeiro chamou os apóstolos de pescadores e depois de sal, porque "importa pouco o ter tomado, se se não conservar o que se tomou" (2011, p.310)

8 As transcrições do "Sermão de Santo Antônio aos peixes" são indicadas apenas pelo número da página em que se encontram a partir da segunda citação da obra. Para evitar sobreposição, quando há referências da mesma página, no mesmo parágrafo, elas são indicadas somente uma vez.

9 No sermão, a passagem bíblica aparece em latim.
} 
O movimento de Vieira de dirigir a palavra aos peixes, simulando ignorar a presença das pessoas que assistiam ao sermão, e dispensando-as, traz à tona a revolta do religioso frente à indiferença dos fiéis quanto à exploração humana praticada pelos colonos do Maranhão. A par disso, o discurso articula-se como estratégia retórica cujo resultado pode ser positivo, visto que, ao mesmo tempo em que são redirecionadas, as palavras alcançam o objetivo, pois o conteúdo expresso se orienta à plateia - constituída de pessoas -, que se defrontam com uma alegoria, à medida em que são representadas por peixes.

À certa altura do sermão, o padre se dirige aos presentes: "Ah moradores do Maranhão, quanto eu vos pudera agora dizer neste caso! Abri, abri estas entranhas: vede, vede este coração". No entanto, corrige-se, em seguida, afirmando: "Mas ah sim, que me não lembrava! Eu não vos prego a vós, prego aos peixes" (p.439). A estratégia retórica, ao mesmo tempo em que reforça o desprezo ao público, materializa sua presença, estimula sua atenção e provoca uma reação.

É com um elogio aos peixes que a segunda parte do Sermão Vieira inicia: "Ao menos têm os peixes duas boas qualidades de ouvintes: ouvem e não falam" (p.432). O encômio distingue os seres do mar dos humanos, e o leitor pode inferir que estes estão destituídos das virtudes citadas, tão caras a um pregador. Logo após o louvor às qualidades dos peixes, Vieira admite a presença de bons e maus, tanto entre as pessoas quanto no meio dos peixes. Diante dessa realidade, esclarece que cabe ao pregador louvar (as virtudes) e repreender (os vícios), procedimento que será tomado ao longo do sermão, com o qual pretende alcançar os objetivos de agradar, persuadir, educar e ensinar os preceitos da fé cristã.

Vieira, inicialmente, ocupa-se em louvar seu público, lembrando os peixes de que foram os primeiros a serem criados e nomeados por Deus. Arrola, em seguida, outras situações em que eles foram valorizados. Encerra, em determinado momento, a exemplificação para repreender a quem de fato o está assistindo: "Estes e outros louvores, estas e outras excelências de vossa geração e grandeza vos pudera dizer, ó peixes; mas isto é lá para os homens, que se deixam levar destas vaidades, e é também para os lugares em que têm lugar a adulação, e não para o púlpito" (p. 433).

Dito isto, o autor começa a enumerar e comentar as virtudes dos peixes. A primeira delas é a obediência, que, conforme o pregador, se tornou evidente quando os peixes ouviram a palavra de Deus pronunciada por Santo Antônio, ao contrário dos homens, que o perseguiram porque ele repreendera seus vícios. Quem olhasse para o mar e visse os peixes quietos e devotos e, para a terra, onde os homens se encontravam furiosos e obstinados, só poderia concluir que "os peixes irracionais se tinham convertido em homens, e os homens não em peixes, mas em feras" (p.434). Neste caso, continua, "os homens tinham a razão sem o uso, e os peixes o uso sem a razão". Além desse exemplo, o pregador relata o episódio em que Jonas foi salvo por um peixe, que o engoliu para devolvê-lo a salvo à terra ${ }^{10}$.

Para que suas palavras ferissem ainda mais os ouvidos dos presentes, o jesuíta recupera a afirmação de Aristóteles de que só os peixes não se deixam domar nem domesticar e declara que, ao contrário do que muitos pensam, não condena essa atitude e recomenda: "Peixes! Quanto mais longe dos homens tanto melhor: trato e familiaridade com eles, Deus vos livre" (p.435). A estratégia de empregar o vocativo é um recurso para aproximar os destinatários da pregação, as pessoas, a quem, no entanto, menciona por meio da terceira pessoa do plural - eles -, como se estivessem ausentes do locus enunciativo. Em seguida, com o intuito de reforçar a aporia entre animais e humanos, o pregador recupera o evento bíblico do dilúvio e vale-se da justificativa de Santo Ambrósio sobre o fato de apenas os peixes serem exceção em relação à formação de casais. Afirma Vieira no sermão:

[...] como o dilúvio era um castigo universal que Deus dava aos homens por seus pecados, e ao mundo pelos pecados dos homens, foi altíssima providência da divina justiça que nele houvesse esta diversidade ou distinção, para que o mesmo mundo visse que da companhia dos homens the viera todo o mal; e que por isso os animais que viviam perto deles, foram também castigados e os que andavam longe ficaram livres (p. 436)

Apesar da transgressão da lógica - os peixes não foram preservados na sua totalidade por não terem contato com os humanos, mas por viverem nas águas e, assim, terem condições de resistir a um dilúvio -, Vieira reforça sua posição proclamando: "Vede, peixes, quão grande bem é estar longe dos homens" (p.436). Enfatizando seu ponto de vista, o jesuíta encerra a segunda parte do sermão fazendo referência a Santo Agostinho que, "para fugir dos homens deixou a casa de seus pais e se recolheu ou acolheu a uma religião, onde professasse perpétua clausura" (p.437). Pronuncia o pregador:

Para fugir e se esconder dos homens, mudou de hábito, mudou de nome, e até a si mesmo se mudou, ocultando sua grande sabedoria debaixo da opinião de idiota, com que não fosse conhecido nem buscado, antes deixado de todos, como lhe sucedeu com seus próprios irmãos no capítulo geral de Assis. Dali se retirou a fazer vida

\footnotetext{
${ }^{10}$ Episódio narrado em Jonas 1: 17.
} 
solitária em um ermo, do qual nunca saíra se Deus como por força o não manifestara, e por fim acabou a vida em outro deserto tanto mais unido com Deus quanto mais apartado dos homens.

Uma invocação aos peixes dá início à terceira parte do sermão: "Este é, peixes, em comum o natural que em todos vós louvo, e a felicidade de que vos dou o parabém, não sem inveja" (p.437). Vieira passa a avaliar particularidades das virtudes da família dos peixes. O primeiro que cita é "aquele santo peixe de Tobias", que apareceu diante do jovem, de boca aberta, quando ele lavava seus pés à margem do rio. Tobias, aconselhado pelo anjo Rafael, puxou o animal para a terra e extraiulhe o fel, o coração e o fígado, remédios para doenças físicas e psíquicas. O fel serviu para curar a cegueira do pai de Tobias e o coração para espantar o demônio de sua própria casa. O Padre compara o peixe a Santo Antônio: "Certo que se a este peixe o vestiram de burel e o ataram com uma corda, parecia um retrato marítimo de Santo Antônio" (p. 438), e a atitude de Tobias diante do peixe com o comportamento dos hereges diante dos sermões de Santo Antônio: tanto aquele como estes gritaram e se assombraram, pensando que iriam ser comidos. Diante da reação dos hereges, Vieira assevera: "Ah homens, se houvesse um anjo que vos revelasse qual é o coração desse homem, e esse fel que tanto vos amarga, quão proveitoso e quão necessário vos é!" (p.438).

Para concluir o raciocínio sobre os eventos que envolvem o peixe e Santo Antônio, afirma que só vê uma diferença entre eles: "o peixe abria a boca contra quem se lava, e Santo Antônio abria a sua contra os que se não queriam lavar" (p. 439), julgando e condenando as pessoas que não quiseram ouvir as palavras do pregador. A crítica também é destinada a seu público, aos colonos portugueses a quem nomeia, simulando um engano, que corrigiria logo a seguir: "Ah moradores do Maranhão, quanto eu vos pudera agora dizer neste caso! Abri, abri estas entranhas; vede, vede este coração. Mas ah sim, que me não lembrava! Eu não vos prego a vós, prego aos peixes" (p. 439). O pronome demonstrativo "neste" pode se referir tanto à situação relatada quanto a do presente; o substantivo "coração" também pode nomear tanto o de um quanto de outro pregador. Há uma interpelação direta e incisiva - a repetição de "abri" e "vede" confirmam isso - para que o público olhe o interior do pregador que está diante dele e veja que seu objetivo é curar a cegueira e espantar o demônio. Portanto, a interpelação aos hereges do tempo de Santo Antônio é dirigida, de fato, ao público que está diante de Vieira, estabelecendo-se, assim, uma relação entre o santo e o pregador, cujos objetivos são análogos e cujas palavras são como o fel que cura. Faz-se necessário registrar que Vieira usa a linguagem culta do sistema colonial, a fim de subverter a própria condição do colonizador, reestruturando suas imagens imaculáveis do imaginário, adaptando-as à rede de significação daquele contexto específico.

Após, Vieira incorpora a seu discurso a "rêmora", um peixe de pequeno porte que se deixa transportar por peixes maiores, tartarugas, barcos. $\mathrm{O}$ animal, agarrado ao leme da nau, é "freio da nau e leme do leme" (p.439), pois prende e agarra mais que as âncoras e consegue determinar seu rumo. Assim é a língua de Santo Antônio, afirma Vieira, a qual doma as paixões humanas, como as que habitam a "nau Soberba", a "nau Vingança", a "nau Cobiça" e a "nau Sensualidade". Os homens dessas naus foram salvos por Santo Antônio que, como rêmora, pôs a mão no leme até que as velas amainassem.

Uma vez mais, o exemplo é direcionado aos colonos do Maranhão, cujas "naus" têm as mesmas características das nomeadas: a soberba, defeito visível entre os colonizadores; a vingança, que emerge quando os colonizadores são desafiados pelos jesuítas; a cobiça, que se revela no propósito dos colonos de enriquecer a qualquer custo; e a sensualidade dos indivíduos, caracterizada pela maneira como lidam com os bens materiais e com eles se iludem.

O torpedo é outro peixe referido pelo padre em seu sermão. No entanto, antes de discorrer sobre as virtudes dele, observa que a rêmora e o torpedo são conhecidos no lugar "mais de fama que de vista". Para ele, isso ocorre com "as virtudes grandes" que, quanto maiores são, "mais se escondem" (p. 440). O comentário tem o propósito de salientar que a humildade é essencial ao virtuoso, que não precisa ser afamado para servir de exemplo.

O torpedo, explica Vieira, quando preso ao anzol, faz o braço do pescador tremer, por causa da eletricidade que é capaz de produzir. "Pode haver maior, mais breve e mais admirável efeito"? (p. 441), pergunta. Esse efeito resulta de uma virtude e permite uma analogia com os pescadores da terra, que ele enumera a partir dos objetos "pescados", reveladores de sua ganância: "No mar pescam as canas, na terra pescam as varas (e tanta sorte das varas), pescam as ginetas, pescam as bengalas, pescam os bastões e até os cetros pescam, e pescam mais que todos, porque pescam cidades e reinos inteiros" (p.441). No entanto, por seu espanto, revela, eles não atingem o efeito do torpedo, seus instrumentos são incapazes de transportar a energia de maneira a obter êxito na conversão das pessoas, tal qual Santo Antônio, que fez com que vinte e dois pescadores se lançassem a seus pés e, tremendo, confessassem seus furtos, restituíssem o que lhes era possível e mudassem de vida e de ofício.

O quarto peixe virtuoso referido por Vieira é o quatro-olhos, que vira em uma viagem ao Pará. "Tantos instrumentos de vista a um bichinho do mar, nas praias 
daquelas mesmas terras vastíssimas, onde permite Deus que estejam vivendo em cegueira tantos milhares de gentes há tantos séculos?" (p.442), pergunta-se, em referência aos nativos que desconhecem os ensinamentos divinos. Olhando atentamente para o peixe revela que percebeu os pares de olhos dispostos de maneira que o peixe possa observar tanto o mar como o céu, visto que, em ambos os espaços, possui inimigos: os peixes maiores e as aves marítimas. $\mathrm{O}$ ensinamento deste peixe é que só se deve olhar para cima, para o Céu, e para baixo, para o Inferno, para que não se veja a vaidade, "porque neste mundo tudo é vaidade" (p.443). Novamente, faz menção a um dos pecados humanos, dimensionando seu alcance.

Para finalizar, Vieira dirige-se aos peixes, louvandoos por sua contribuição aos que buscam alcançar o Céu. Lembra que eles sustentam os religiosos das ordens e as famílias cristãs, presentificam a penitência das Quaresmas e estavam nas duas ocasiões em que Cristo comeu com seus discípulos, depois de ressuscitado. Em oposição às aves e animais terrestres, que fazem "esplêndidos e custosos os banquetes dos ricos", os peixes podem se vangloriar de serem "companheiros do jejum e da abstinência dos justos" (p.443). Conclui afirmando que são os peixes criaturas do elemento que é próprio da fecundidade, a água. Aconselha-os, para finalizar os louvores, que tomem o exemplo das sardinhas, que são o sustento dos pobres, enquanto os solhos e os salmões alimentam os reis e os poderosos.

Vieira, a seguir, faz uma repreensão: "A primeira cousa que me desedifica, peixes, de vós, é que vos comeis uns aos outros". Ao afirmar que "Grande escândalo é este, mas a circunstância o faz ainda maior. Não só vos comeis uns aos outros, senão que os grandes comem os pequenos" (p.445), faz uma crítica aos sujeitos daquele espaço e uma referência à situação que se criou entre os colonos portugueses e os indígenas, valendo-se de uma expressão de Santo Agostinho: "Os homens, com suas más e perversas cobiças, vêm a ser como os peixes que se comem uns aos outros" (p. 445). Observa que, enquanto Santo Agostinho pregava aos homens mostrando a fealdade dos peixes, ele fazia o contrário, com o intento de mostrar aos peixes o quanto é abominável o que fazem. Entretanto, reforçando os traços de seu público imaginado, maldiz acerbamente os colonos portugueses: "Olhai, peixes, lá do mar para a terra. Não, não: não é isso que vos digo. Vós virais os olhos para os matos e para o sertão? Para cá, para cá; para a cidade é, que haveis de olhar. [...] Cuidais que só os tapuias se comem uns aos outros, muito maior açougue é o de cá, muito mais se comem os brancos" (p. 445). Para ele, a agitação da cidade, em que as pessoas andam sem sossego, mostra sua incessante e sôfrega busca por alguém a quem devorar.
Para elucidar esse comportamento de aniquilação do outro, Padre Vieira dá como exemplo as práticas da sociedade quando alguém morre:

\begin{abstract}
Morreu algum deles, vereis logo tantos sobre o miserável a despedaçá-lo e comê-lo. Comem-no os herdeiros, comem-no os testamenteiros, comem-no os legatários, comem-no os acredores: comem-no os oficiais dos órfãos, e os dos defuntos e ausentes: come-o o médico, que o curou ou ajudou a morrer, come-o o sangrador que lhe tirou o sangue, come-o a mesma mulher, que de má vontade lhe dá para mortalha o lençol mais velho da casa, come-o o que lhe abre a cova, o que lhe tange os sinos, e os que cantando o levam a enterrar: enfim, ainda o pobre defunto o não comeu a terra, e já o tem comido toda a terra (p. 445, 446).
\end{abstract}

Após enumerar uma série de pessoas que se aproveitam do defunto para obter benefícios, em nome da ganância, o pregador observa que não só os mortos comem os homens, mas também os vivos, assim como os peixes. Traz, então, a figura bíblica de Jó e propõe aos peixes que olhem para os perseguidos da terra, para ver quantos estão comendo o defunto: "Come-o o meirinho, come-o o carcereiro, come-o o escrivão, come-o o solicitador, come-o o advogado, come-o o inquiridor, come-o o testemunha, come-o o julgador, e ainda não está sentenciado, já está comido" (p. 446). "São piores os homens que os corvos", desabafa, em um intento explícito de impressionar o público e fazê-lo ver o quanto são desprezíveis suas atitudes no dia a dia.

Ao assinalar que são os pequenos, os fracos que sofrem a maldade dos grandes e suas consequências, Padre Vieira vale-se de passagens bíblicas, cuja voz autoral é a do próprio Deus, afim de reforçar a denúncia dos abusos em voga à época, em que os poderosos submetem os humildes a seus caprichos. Mais uma vez, Vieira invoca seu público: "Parece-vos bem isto, peixes?", interrogando-os por ter observado uma reação negativa quanto ao que expusera a respeito da maldade dos homens. "Pois isto mesmo é o que vós fazeis" (p. 447), assinala. A estratégia de apontar a não concordância dos peixes com sua acusação propõe a ideia de que quem está fora do contexto humano não acredita na maldade, revelação essa que assume status de verdade para o público acusado de praticar o mal.

Neste ponto do sermão, o pregador ataca, de forma explícita, os colonos portugueses, ao observar que os mais velhos entre os peixes viram ou ouviram sobre a destruição da terra: "Os maiores que cá foram mandados, em vez de governar e aumentar o Estado, o destruíram; porque toda a fome que de lá traziam, a fartavam em comer e devorar os pequenos" (p. 448). Observa que em 
Portugal, esses mesmos que aqui comem, são comidos pelos maiores de lá, evidenciando uma relação arquetípica do poder colonial. "Este é o estilo da Justiça Divina", adverte, com o objetivo de vincular a plateia à proposição de que a justiça está presente quando não permite que os "grandes" sejam soberanos em todos os lugares.

Após esclarecer a situação dos colonos, implora que todos sejam mais "repúblicos e zelosos do bem comum", para que se reverta o quadro em que muitos são explorados a ponto de chegar à aniquilação da vida. Clama aos peixes que terminem com esta "perniciosa discórdia" e vivam como irmãos para que alcancem a felicidade. A súplica interrompe o processo de acusação que Vieira constrói até aqui quando refere os defeitos dos peixes (dos humanos) e se instala como um conselho. Portanto, o pregador exerce sua autoridade para conclamar o povo para um novo comportamento, com o argumento de que a terra oferece o suficiente para que todos possam se sustentar.

Em seguida, Vieira volta às acusações ao falar da ignorância e da cegueira que leva os peixes a se lançar em direção a um pano preso a um cabo e jogado ao mar. Para ele, isso é consequência da vaidade, que também atinge os humanos nas guerras. Didatiza, referindo-se ao hábito de Malta, de Avis, de Cristo e de Santiago, cujos panos os homens colocam no peito para serem tragados e engolidos a ferro. Na passagem, critica o procedimento das ordens religiosas que se valem de estratégias militares para expandir e implantar a ideologia cristã. Para ele, o recrutamento de pessoas para lutar em defesa e expansão do cristianismo, levando-as à morte, não faz parte da essência de uma ordem religiosa, que deveria se dedicar à espiritualidade das pessoas, ensiná-las e educá-las. Continuando, Vieira dirige-se ao público e argui, com o intuito de provocar a uma reflexão sobre a realidade: "Quem pesca as vidas a todos os homens do Maranhão, e com quê?". E responde: "Um homem do mar com os retalhos de pano" (p. 451), em referência aos mercadores portugueses que, à época, se aventuravam nas colônias portuguesas para vender seus produtos. Vieira critica a prática do consumismo em que, por um lado, há a oferta e a exploração e, por outro, a vaidade:

Isca com aqueles trapos os moradores da nossa terra: dá-lhes uma sacadela e dá-lhes outra, com que cada vez lhes sobe mais o preço: e os bonitos, ou os que querem aparecer, todos esfaimados aos trapos, e ali ficam engasgados e presos, com dívidas de um ano para outro ano, e de uma safra para outra safra, e lá vai a vida (p. 451).

Para o pregador, a cultura do consumo é injusta, pois o dinheiro que dela resulta não se destina a quem investiu sua vida na produção do produto. Investe, Vieira, no quinto capítulo, em um dado particular, com o objetivo de esclarecer o que tem contra alguns dos peixes - leiase sujeitos do espaço da colônia. Para tanto, cita quatro tipos de peixes - o roncador, o pegador, o voador e o polvo - valendo-se do mesmo procedimento de quando tratou das virtudes. O roncador, revela, provoca-lhe tanto o riso como a ira: o primeiro, por causa do descompasso entre o tamanho do peixe e seu ronco; o segundo, porque o ronco é uma farsa. O ronco deve ser condenado quando vem dos grandes - neste caso é a arrogância, como a da baleia, gigante dos mares. Cita o caso que envolveu o gigante Golias, derrotado pelo pequeno Davi. Para todos os roncadores, aconselha calar e imitar a Santo Antônio, que aliava o poder ao saber - dois atributos que fazem roncar -, mas nunca deixou de calar, o que lhe permitiu dar tamanho brado. Mais uma vez as palavras de Vieira estão direcionadas aos colonos portugueses, que se valem de seus conhecimentos e do seu poder para explorar o trabalho humano, escravizando indígenas e defendendo seus interesses contra quem se opõem a eles, como os próprios padres jesuítas.

Outro tipo de peixe mencionado por seus defeitos é o pegador que, como o próprio nome diz, são animais que não só se acercam a outros maiores que eles como "se lhes pegam aos costados que jamais os desaferram” (p. 454). Vieira está se referindo aos bajuladores e aproveitadores de autoridades que, não tendo competência para o êxito, estão à sombra de quem os possa favorecer. Anuncia ele: "[...] não parte vice-rei, ou governador para as conquistas que não vá rodeado de pegadores, os quais se arrimam a eles, para que cá lhes matem a fome, de que lá não tinham remédio" (p. 455). No entanto, explica ao público, os pegadores morrem, tão logo o tubarão, a que estão colados, é abatido. Ao alertar a plateia sobre o erro que é viver em tais circunstâncias, o Padre denomina os pegadores de "peixinhos ignorantes e miseráveis" qualificação que é extensiva aos humanos. E, ao final, pergunta: "Pode haver maior ignorância que morrer pela fome e boca alheia?" (p. 457).

O terceiro peixe enumerado por Vieira é o voador, sua imagem é usada para recriminar a ambição: são peixes que, tendo barbatanas maiores, não contentes com sua condição, querem ser aves. Agindo dessa maneira, adverte, deixam de ser peixe e não conseguem ser ave, ou seja, não são coisa alguma. Assim, sentencia: "Quem quer mais do que lhe convém, perde o que quer, e o que tem" (p. 458). Ao aconselhar os peixes, deixa claro que não fala aos humanos, em uma clara tentativa de provocar a plateia humana, insinuando que a ela pouco vale dar conselhos: "Voadores do mar (não falo com os da terra), imitai o vosso santo Pregador" (p. 459).

O último peixe a ser citado no sermão por Vieira é o polvo, que, "com aquele seu capelo, parece um monge; com aqueles seus raios estendidos, parece uma estrela; 
com aquele não ter osso nem espinha, parece a mesma brandura, a mesma mansidão", mas que se constitui no “maior traidor do mar". A primeira traição do polvo está no vestir, pois muda conforme as circunstâncias, para prender sua presa. Ele é pior que Judas, afirma Vieira, pois este só abraçou a Jesus, e outros o prenderam; o polvo, afirma, faz as duas coisas: abraça e prende.

Mesmo que a acusação da passagem vise aos colonos maranhenses, a história do jesuíta permite alargar esse alvo, uma vez que ele enfrentou calúnias, movidas pela inveja, processo que enfraqueceu sua posição na corte portuguesa. Para João Adolfo Hansen, é possível que a crítica também seja destinada à congregação dos carmelitas e a dos dominicanos: "Significando hipócritas em geral, ela [a alegoria] também parece aludir a carmelitas, inimigos de Vieira em São Luís, e a dominicanos, seus velhos inimigos do Santo Ofício, no Reino" (1999, p. 40).

Na parte dos louvores e repreensões, faz uma última advertência, dizendo que muitos navios se perdem no mar, enriquecendo-o com os produtos da terra. Quem se enriquece com essas riquezas, adverte aos peixes, fica excomungado e maldito. Mas, como a excomunhão é imposta aos humanos, os peixes são penalizados de outra maneira: definham até acabar miseravelmente. A seguir recorre a um exemplo: São Pedro, necessitando de dinheiro para pagar um tributo, recebeu de Jesus a recomendação de que fosse pescar, pois encontraria uma moeda na boca do primeiro peixe que pegasse, o que se concretizou. Aqueles que obtêm bens dos naufragados, tal como o peixe de São Pedro, são os mais vulneráveis, e os primeiros a morrer "com o mesmo dinheiro que engoliram atravessado na garganta". Ao dizer isso, novamente menciona os humanos que estão diante dele: "Oh que boa doutrina era esta para a terra, se eu não pregara para o mar!". E continua: "Para os homens não há mais miserável morte que morrer com o alheio atravessado na garganta; porque é pecado de que o mesmo São Pedro, e o mesmo sumo pontífice não pode absolver" (p. 462).

Nessa última reprimenda, o Padre Vieira refere-se à indevida apropriação dos bens alheios por parte dos colonizadores, afirmando que a ocupação de novas terras são invasões, em cujo processo os colonos se apropriam da terra dos nativos, tornando-os, em muitos casos, seus escravos.

No sermão, antes de propor aos peixes que louvem a Deus pelo que são, Vieira explica-lhes por que eles ficaram de fora dos sacrifícios: porque eram os únicos animais que não podiam chegar vivos ao sacrifício, e Deus não quer que se lhe ofereçam mortos. Este ponto também seria importante e necessário pregar aos homens, observa, visto que, muitos deles, chegam mortos ao altar de Deus, em pecado mortal.

\section{Considerações finais}

O "Sermão de Santo Antônio aos Peixes", pela via dos elogios e das advertências, ensinamentos, aconselhamentos, explicações aos habitantes do mar, público escolhido e anunciado por Vieira - apesar de estar diante da população de São Luís do Maranhão - aponta, a cada linha, para traços do ser humano e da sociedade da época em que foi produzido, estruturando um panorama das virtudes e dos problemas sociais vigentes. Dessa maneira, constitui-se em documento literário privilegiado de acesso à cultura vigente no sistema colonial brasileiro. Para Alfredo Bosi, no sermão, que considera "uma das mais ardidas e chistosas sátiras com que [Vieira] fustigou os vícios contumazes dos maranhenses" (2011, p.53), "a exemplificação vem em cascata traçando um quadro móvel da sociedade colonial com o foco na voracidade dos ricos e poderosos que arrancam dos pares ou dos humildes tudo quanto podem" (2011, p. 55).

Dessa forma, é possível afirmar que o autor, a partir de um texto cuja "artificialidade" fica evidente, reúne elementos dispersos e inapreensíveis de seu meio para organizá-los, reconfigurá-los e devolvê-los à população de maneira nítida, transparente, para que esta possa reconhecer seus equívocos e, a partir disso, buscar sua própria transformação e, por consequência, do contexto em que vive. Instituída essa mudança, os nativos seriam os maiores beneficiados, à medida em que receberiam de seus algozes melhor tratamento.

No entanto, há um detalhe na elaboração do quadro - não expresso no sermão, mas inscrito na própria atuação do Padre - que precisa ser levado em conta: Vieira, ao mesmo tempo em que luta para libertar os nativos dos colonos, para devolver-lhes a humanidade afanada, representa uma instituição empenhada em arrebanhar indígenas por meio do processo de catequização. Esta caracterizava-se, em especial, pela transmissão dos preceitos da religião católica, visando à conversão, mas, também, pelo ensino da língua portuguesa, da música, do teatro, dos costumes europeus, vetores primeiros da empresa colonial. Portanto, igualmente aqui, o direito dos nativos de viver a liberdade, de acordo com sua cultura, não é significado. É possível afirmar que o processo de colonização do Brasil envolveu o cerceamento da liberdade dos povos que habitavam o território, ou para fins de mão de obra escrava, ou com o objetivo de submetê-los a disposições da fé cristã.

O leitor de Vieira, assim, pode constatar contradições em sua prática, na medida em que ele pretende cristianizar os nativos e equipará-los aos portugueses, tirando-os de um estado de carência, de desamparo, negando-lhes, porém, o direito de assumir suas próprias crenças, de 
significar em sua própria malha imaginária. Entretanto, o leitor contemporâneo precisa considerar Vieira como um homem de seu tempo, o que justifica sua aparente contradição e o coloca, inclusive, na condição de moderno, na medida em que a disseminação da fé e a conversão para o cristianismo eram metas de alto valor humanitário. Não é demais, recuperar Saraiva e Lopes (2010, p.517), quando observam que o autor personificava "a situação de um homem de formação religiosa ainda medieval mas com a consciência empírica das novas condições sociais e europeias da realidade social e econômica portuguesa", procurando soluções para as emergências paradoxais daquele quinhão histórico.

Resta destacar que a importância do "Sermão de Santo Antônio aos Peixes" não se restringe à representação das ideias de Vieira, mas a sua qualidade estética, que revela um autor com domínio absoluto da linguagem retórica. Ao falar a seu povo, Vieira consegue falar à humanidade, erosionando as fronteiras espaciais e temporais, e inserindo seu sermão no rol das obras de qualidade indiscutível da literatura brasileira, o que justifica sua permanente condição de objeto de análise, uma vez que sua materialidade ficcional, metáfora do imaginário colonial de Portugal, perpetua parte significativa do patrimônio histórico de nosso país.

\section{Referências}

ALMEIDA, Candido Mendes de. Memórias para a história do extincto estado do Maranhão, cujo território compreende hoje as províncias do Maranhão, Piauhy, Grão-Pará e Amazonas. Rio de Janeiro: Typ. do Commercio, de Brito \& Braga, 1860. Disponível em: $<$ https://books.google.com.br/books?id=9Nw 4AQAAMAAJ\&pg=PA323\&lpg=PA323\&dq=Chegada + Pe . + Vieira + no + Maranh $\%$ C3\%A3o\&source $=$ bl\&ots $=5 \mathrm{MPeB} 3 \mathrm{x}$ un8\&sig=XmmDs7ZNHfBBWUt7Y2N48CzSmMc\&hl=en $\& s a=X \& e i=i 9 i r V I b A B c m p g w T k u o P A B Q \& v e d=0 C C 0 Q 6 A E$ $\mathrm{wAg} \# \mathrm{v}=$ onepage $\& \mathrm{q}=$ Chegada $\% 20 \mathrm{Pe} . \% 20$ Vieira $\% 20$ no $\% 20$ Maranh\%C3\%A3o\&f=false>. Acesso em: 3 out. 2017.

AZEVEDO, João Lúcio de. História de Antônio Vieira. Tomos I e II. São Paulo: Alameda, 2008.

Cartas. 4v. Rio de Janeiro: Globo, 2008.
BAPTISTA, Maria Manuel; FRANCO, José Eduardo. António Vieira, esse povo de palavras. In: Ideação: Revista do Núcleo Interdisciplinar de Estudos e Pesquisas Filosóficas da Universidade Estadual de Feira de Santana - Feira de Santana - v. 1, n. 1 (1997-) v. 1, n. 19, jan./jun. 2008.

BESSELAR, José van den. António Vieira: o homem, a obra, as ideias. Lisboa: Instituto de Cultura e Língua Portuguesa. Ministério da Educação e Ciência 1981.

BÍBLIA DE ESTUDO DE GENEBRA. São Paulo e Barueri: Cultura Cristã e Sociedade Bíblica do Brasil, 1999.

BOSI, Alfredo. Antônio Vieira: vida e obra - um esboço. In: VIEIRA, Antônio. Essencial Padre Antônio Vieira. Organização e introdução de Alfredo Bosi. São Paulo: Penguin Classics, Companhia das Letras, 2011.

Vieira, ou a cruz da desigualdade. São Paulo: Novos Estudos, n. 25, outubro de 1989. Letras, 1992.

Dialética da colonização. São Paulo: Companhia das DURAND, G. O imaginário. Rio de Janeiro: Diffel, 1994.

HANSEN, João Adolfo. Padre Antônio Vieira: sermões. In: MOTA, Lourenço Dantas (org.). Introdução ao Brasil: um banquete no trópico. São Paulo: Ed. SENAC, 1999.

IBGE. Disponível em: <http://brasil500anos.ibge.gov.br/ territorio-brasileiro-e-povoamento/historia-indigena/politicaindigenista-do-seculo-xvi-ao-seculo-xx>. Acesso em 26 mar. 2015.

PALACIN, Luís Gómez. Entre o reino imperfeito e o reino consumado. São Paulo: Loyola, 1988.

SARAIVA, A. J.; LOPES, Óscar. História da literatura portuguesa. Porto: Porto Editora, 2010.

VIEIRA, Antônio. Cartas do Padre Antonio Vieira revistas por Tito de Noronha. Porto: 1871. Disponível em: <https://books. google.com.br/books?id=-9E5AQAAMAAJ\&pg=PA53\&lp $\mathrm{g}=$ PA53\&dq $=$ Pe. + Vieira $\% 2 \mathrm{Bcarta}+\mathrm{de}+20+\mathrm{de}+$ maio $+\mathrm{de}+16$ $53 \&$ source $=$ bl\&ots $=5$ jdt1BZJY\&sig $=$ HeSaMXd8tYjRHwa i2fS6svGCm1s\&hl=pt-BR\&sa=X\&ei=SWauVMW-GISzeovgbgE\&ved=0CDEQ6AEwAw\#v=onepage \&q=Pe. $\% 20$ Vieira $\% 2$ Bcarta $\% 20$ de $\% 2020 \% 20$ de $\% 20$ maio $\% 20$ de $\% 20$ $1653 \& \mathrm{f}=$ false $>$. Acesso em 09 jan. 2015.

Recebido:12 de outubro de 2017 Aprovado: 20 novembro 2017 Contato: ernani@feevale.br (Ernani Mügge) danielconte@feevale.br (Daniel Conte) 